\title{
Introduction: Language policies on social network sites
}

\author{
Julia de Bres ${ }^{1}$
}

Received: 10 April 2015/Accepted: 13 April 2015/Published online: 24 May 2015

(C) Springer Science+Business Media Dordrecht 2015

Research on language policy has progressed in recent decades from a focus on the language policies of government agencies to policies within a much broader range of domains, such as the workplace, the family, the public space, and the media (Spolsky 2009). Recognising that the official policy of a setting may bear little relationship to the de facto language norms operating within it, this research has also developed from an emphasis on explicit language policies to policies taking more implicit forms (Shohamy 2006; Spolsky 2004), In this regard, it is now generally accepted that policies need to be understood in the context of the language practices of their target audience and their associated language ideologies. Stronger forms of this view go so far as to claim that the 'language policy' of a certain setting can only be understood as the sum total of the policies, practices and ideologies operating within that environment (Spolsky 2004). Within this view, language policy is a dynamic composite of elements, constantly under construction and always subject to change.

The expanded view of language policy has also drawn attention to a broader range of language policy agents. When exploring a wider range of domains with attention to both explicit and implicit forms of policymaking, it becomes clear that not simply government officials but also parents, bosses, colleagues, sports coaches, friends, can and do engage in making and modifying language policies. While some theorists claim that doing so requires some kind of actual or perceived authority on the part of the policymaker, e.g. status as a parent (Spolsky 2009), this may not necessarily be the case. Indeed, if we take seriously the notion that practices make

Julia de Bres

julia.debres@uni.lu

1 Institute of Luxembourgish Language and Literatures, University of Luxembourg, Campus Walferdange, Route de Diekirch, 7201 Walferdange, Luxembourg 
up an essential part of any language policy, every interaction in which we engage can be seen as an instance of language policy activity: with each word we speak or write, we either align with, modify, or resist the language norms operating (implicitly or explicitly) in that setting. Taking this view to its logical conclusion, language policy arguably becomes indistinguishable from language use itself. At this point, some researchers in language policy are likely to protest that the term becomes meaningless. And indeed, in practical terms, most language policy researchers focus on instances where individuals or groups engage in more concrete strategic attempts to manage language behaviour. From this perspective, language policy can be defined as any activity in which a social actor attempts to modify the language practices, language ideologies, or, indeed, language policies, of others.

Among the greater range of domains identifiable as potential settings of language policy activity, the new media presents a compelling setting for investigating language policies. Research on language in the new media has grown rapidly in recent years, alongside an ever-increasing interest in digital environments within social science research. Sociolinguistic research on language in the new media has investigated language use in a wide range of online environments, including gaming, messaging, discussion forums, media sharing sites, blogs and encyclopedias (Thurlow and Mroczek 2011; Kelly-Holmes and Milani 2011; Danet and Herring 2007; Ensslin 2011). Some of this research concentrates on social network sites (SNS), with a particular focus to date on Facebook (e.g. Jones et al. 2011; Lee 2011; Wagner 2011; Bolander and Locher 2010). This research has, however, tended to focus on language practices (e.g. code-switching, language play, style shifting, identity construction) rather than the language policies that attempt to guide them (see, however, Lenihan 2011, 2013 for an exception). In 2009, Androutsopoulos observed that media in general 'is not a key concept in language policy research' and that 'many areas of mediated communication are still largely uncharted territory in terms of language policy' (2009: 285). Examining SNS as a site of language policy thus brings together trends at the forefront of current research on both language in the new media and language policy.

While titled 'Language policies on social network sites', the articles included in this thematic issue all treat one SNS in particular: Facebook. Created in 2004, Facebook had 1.39 billion monthly active users as of December 2014 (Facebook 2015), representing a steady increase per quarter since 2008 (Statista 2015). In a sense, the exclusive focus on Facebook is an editorial accident: a call for papers targeting research on SNS in general resulted exclusively in responses relating to Facebook. This is likely to be due to the current global prominence of this SNS. Despite its American origins, over $80 \%$ of Facebook users are currently located outside the US or Canada (Facebook 2015). Developments in digital media happen so fast that within a few years it may well be the case that Facebook no longer assumes this predominant role either among SNS in general, or in research on SNS in particular. With its specific focus on one SNS, this issue does not reflect at all the global diversity in SNS, which vary considerably in terms of structure, languages used, and popularity in different parts of the world. Nevertheless, an exclusive focus on one SNS, with all its particularities, also presents advantages, particularly in that 
it enables us to examine in some detail within one specific online context just how much language policy activity is occurring, and in how many different forms.

The papers included in this issue address a wide range of language situations, including Facebook contexts involving the languages of Luxembourg, Turkey, Nepal, the Netherlands and the Czech Republic. They address a variety of language policy contexts within Facebook, including the official language policy of Facebook itself (Hendus this issue), the language policies of Facebook groups, some constituted specifically in relation to language (Sherman and Švelch, Yazan, this issue), others created for other reasons (de Bres and Belling, Phyak, this issue), and the language policies of individuals (Hendus, Phyak, this issue). The targets of language policy in the contributions include language choice in multilingual environments, the construction of minority languages, policing orthography, and personal translation practices. In addressing these language policy contexts, the authors make use of a range of theoretical concepts, including various conceptions of language policing (Blommaert et al. 2009), Language Management Theory (Neustupný and Nekvapil 2003; Nekvapil and Sherman 2009), language ideologies (Kroskrity 2000, 2004) and, more specific to this setting, media ideologies (Gershon 2010). The authors use a variety of sociolinguistic methods, including quantitative approaches (questionnaires, corpus analysis), qualitative approaches (analysis of online interaction threads) and a mix of the two. Almost all include some consideration of multimodal aspects of SNS data.

While revealing findings specific to each context, certain common issues emerge across the papers. One of these is attention to the concrete processes of language policy, e.g. use of humour as an instrument of language management (Sherman and Švelch, this issue) or the specific discursive techniques used to promote adherence to an orthographic standard (Yazan, this issue). Another common theme is the orientation of participants in SNS interactions to offline language policies as a means of achieving their language-related goals online (de Bres and Belling, Phyak, this issue). This relates to a parallel question of the extent to which language policy activities on a micro level (in specific online contexts) can or do influence language policy change offline (Yazan, Phyak, this issue). Perhaps the strongest unifying theme of the papers is the sometimes uncomfortable coexistence of heterogeneity in digital language practices with homogeneity in language ideologies expressed online, where diversity and hybridity are often overtly resisted. In this sense, most of the papers reproduce what Blommaert et al. (2009: 204) have referred to as 'modernist responses to postmodern conditions'. More generally, the striking level of language policy activity found in the papers underlines the fact that, while SNS are sometimes seen as unregulated spaces, they in fact represent highly regulated linguistic environments (see also Androutsopoulos 2009).

It is clear from the above that, more than just representing a new domain, research on language policy in SNS has the potential to provide us with new insights on language policy processes in general. Future research in this area could include the following aspects: 
1. Clarification of language policing as theory and process: While of considerable appeal to many researchers, the concept of language policing (Blommaert et al. 2009), has not yet been clearly developed or operationalised, and is conceptualised by researchers in a range of different ways. In this issue, for instance, language policing is alternatively seen as relating to the language policy activities of the state (Yazan, this issue) or of individuals (de Bres and Belling, Phyak, this issue). In terms of a conceptualisation focusing on the policing practices of individuals, more work could be done in analysing the specific techniques individuals use to attempt to direct and modify the practices of others. The context of SNS, with their vast written record of interaction between individuals on metalinguistic issues, provides a very promising focus for furthering this work.

2. Discourse trajectories of language policing: Papers in this issue refer to the fact that some of the visual and/or textual materials presented in the SNS under analysis also appear in other groups and contexts online (Yazan, Sherman and Švelch, this issue). This viral flow of texts and associated discourses is a salient feature of SNS and other online settings. An important focus of further research in this context would be to analyse the digital trajectory of some of these materials, looking at how they are presented and used in different settings. While some of this is beyond the scope of traditional sociolinguistic methods, new approaches deriving from social network analysis could be used to trace the journey of such texts across online contexts, thereby painting a picture of the discourse trajectories of language policing.

3. Consideration of the actual impact of online language policing: The papers in this issue demonstrate that Facebook administrators can assume some languagerelated power over the groups they administer, for instance through setting group language policies, engaging in language ideological debates, and deleting non-conforming posts (de Bres and Belling, Yazan, this issue). Yet it remains clear that, as in other domains of language policy, official policies sometimes have little direct effect on language practices (de Bres and Belling, this issue). Hendus (this issue) points to a probable lack of impact of Facebook language policies unless these already align with users' language practices and associated ideologies. Nevertheless, it is clear that the internet in general and SNS in particular present compelling potential for people to come together and work towards common interests, including those relating to language. It seems likely that some of this interactional work online has broader effects on language practices, policies and ideologies both on- and offline. Finding ways of examining the concrete effects of online language policing both within and outside of the specific online language environments in which they operate presents an important challenge for future research.

4. Methodological development: The points above highlight a further need for rigorous methodological development in approaches to analysing language policy behaviour in SNS and other online contexts. The papers in this issue make use of a range of methods, but have in common that they tend to focus on numerically restricted contexts, such as a small group of users, a single Facebook group or a small number of groups. This is likely to be due both to the 
need to focus on the considerable complexities of even very limited settings, and to the difficulty of capturing and analysing the immense amount of data available online. While small-scale studies clearly provide us with important insights on language policy processes in this setting, it remains a challenge to reliably capture broader trends in a context involving such massive amounts of data. Addressing this issue will probably require a combination of refining existing sociolinguistic methods and taking advantage of increasingly sophisticated software outside of the field, enabling us to analyse connections and trends across larger corpora of data.

At this point, and at the very least, it is hoped that this thematic issue will serve to highlight the considerable interest of SNS for language policy research, and that it will encourage further research on themes that will no doubt only increase in prominence in years to come.

\section{References}

Androutsopoulos, J. (2009). Policing practices in heteroglossic mediascapes: A commentary on interfaces. Language Policy, 2009(8), 285-290.

Blommaert, J., Kelly-Holmes, H., Lane, P., Leppänen, S., Moriarty, M., Pietikäinen, S., \& PiirainenMarsh, A. (2009). Media, multilingualism and language policing: An introduction. Language Policy, $8(3), 203-207$.

Bolander, B., \& Locher, M. A. (2010). Constructing identity on Facebook: Pilot on a pilot study. In K. Junod \& D. Maillat (Eds.), Performing the Self (pp. 165-185). Tübingen: Narr Francke.

Danet, B., \& Herring, S. C. (Eds.). (2007). The Multilingual Internet. New York: Oxford University Press.

Ensslin, A. (2011). What an un-wiki way of doing things: Wikipedia's multilingual policy and metalinguistic practice. Journal of Language and Politics, 10(4), 535-561.

Facebook. (2015). Stats. http://newsroom.fb.com/company-info/. Accessed 10 Apr2015.

Gershon, I. (2010). The breakup 2.0. Disconnecting over new media. New York: Cornell University Press.

Jones, G. M., Schieffelin, B. B., \& Smith, R. E. (2011). When friends who talk together stalk together: Online gossip as metacommunication. In C. Thurlow \& K. Mroczek (Eds.), Digital Discourse: Language in the New Media (pp. 26-47). New York: Oxford University Press.

Kelly-Holmes, H., \& Milani, T. M. (2011). Thematizing multilingualism in the media. Journal of Language and Politics, 10(4), 467-489.

Kroskrity, Paul V. (2000). Regimenting languages: Language ideological perspectives. In P. V. Kroskrity (Ed.), Regimes of language: Ideologies, polities, and identities (pp. 1-34). Santa Fe: School of American Research Press.

Kroskrity, Paul V. (2004). Language ideologies. In Alessandro Duranti (Ed.), A companion to linguistic anthropology (pp. 496-517). Oxford: Blackwell.

Lee, C. K. M. (2011). Micro-blogging and status updates on Facebook: Texts and practices. Digital discourse: Language in the new media (pp. 110-128). New York: Oxford University Press.

Lenihan, A. (2011). Join our community of translators: Language ideologies and/in Facebook. Digital discourse: Language in the new media (pp. 48-64). New York: Oxford University Press.

Lenihan, A. (2013). The interaction of language policy, minority languages and new media: A study of the facebook translations application. Unpublished $\mathrm{PhD}$ thesis. Limerick: University of Limerick. http://ulir.ul.ie/handle/10344/3590.

Nekvapil, J., \& Sherman, T. (Eds.). (2009). Language management in contact situations. Perspectives from three continents. Frankfurt: Peter Lang.

Neustupný, J. V., \& Nekvapil, J. (2003). Language management in the Czech Republic. Current Issues in Language Planning, 4(3-4), 181-366.

Shohamy, E. (2006). Language policy-Hidden agendas and new approaches. Abingdon: Routledge. 
Spolsky, B. (2004). Language policy. Cambridge: Cambridge University Press.

Spolsky, B. (2009). Language management. Cambridge: Cambridge University Press.

Statista (The Statistics Portal). (2015). Number of monthly active Facebook users worldwide as of 4th quarter 2014 (in millions). http://www.statista.com/statistics/264810/number-of-monthly-activefacebook-users-worldwide/. Accessed 10 Apr 2015).

Thurlow, C. \& Mroczek K. (Eds.). (2011). Introduction: Fresh perspectives on new media sociolinguistics. In: Digital Discourse: Language in the New Media (pp. ix-xiv). New York: Oxford University Press.

Wagner, M. (2011). Luxembourgish on Facebook: Language ideologies and discourse types on group pages. Minority languages and the Social Web (pp. 39-52). Frankfurt: Peter Lang.

Julia de Bres is an Associate Professor in Sociolinguistics at the Institute of Luxembourgish Language and Literatures, University of Luxembourg. Her research focuses on language ideologies, policies and practices in relation to minority languages, particularly from a comparative perspective. 